\title{
Metals and metallothionein in the liver of raccoons: utility for environmental assessment and monitoring
}

Joanna Burger, Rutgers University

Christine G. Lord, Rutgers University

Edward J. Yurkow, Rutgers University

Lynn McGrath, Rutgers University

Karen F. Gaines, Eastern Illinois University, et al. 


\title{
METALS AND METALLOTHIONEIN IN THE LIVER OF RACCOONS: UTILITY FOR ENVIRONMENTAL ASSESSMENT AND MONITORING
}

\author{
Joanna Burger, Christine G. Lord, Edward J. Yurkow, Lynne McGrath \\ Division of Life Sciences, Consortium for Risk Evaluation \\ with Stakeholder Participation (CRESP), and Environmental \\ and Occupational Health Sciences Institute, Rutgers University, \\ Piscataway, New Jersey, USA
}

Karen F. Gaines, I. Lehr Brisbin, Jr.

Savannah River Ecology Laboratory, Aiken, South Carolina, USA

\section{Michael Gochfeld}

Environmental and Community Medicine, UMDNJ-Robert Wood Johnson Medical School, Piscataway, New Jersey, USA

The relationship between metallothionein levels and concentrations of several metals and radionuclides was examined in liver tissues of raccoons (Procyon lotor, $n=47$ ) from the Department of Energy's Savannah River Site in South Carolina to determine the applicability of metallothioneins as an initial screening device for exposure assessment in free-living mammals and environmental monitoring. Using a fluorescent marker and a cell sorter to measure metallothionein, a significant positive correlation was found across animals between levels of metallothioneins and concentrations of selenium (Pearson's $r=$ .30 ), mercury (Pearson's $r=.31$ ), and copper (Pearson's $r=.30$ ) in liver tissue. Arsenic, cobalt, silver, thallium, and tin were below detection limits in most or all liver samples. Other metals, including cadmium, chromium, radiocesium $\left({ }^{137} \mathrm{Cs}\right)$, copper, lead, manganese, strontium, and vanadium, showed only weak and nonsignificant correlations with metallothionein. Concentrations of mercury were correlated with concentrations of selenium (Pearson's $r=.73$ ), manganese (Pearson's $r=.56$ ), and strontium (Pearson's $r=.57$ ). In an a posteriori test, there was a still unexplained positive correlation between mercury (Pearson $r=.56$ ), selenium (Pearson $r=.54$ ), and radiocesium (Pearson's $r=.38$ ) concentrations and background cellular autofluorescence, and a negative correlation of strontium with the latter (Kendall tau =-.38). Background cellular autofluorescence may represent a generalized cellular stress response, or a yet unidentified biomarker. To

Received 29 November 1999; sent for revision 29 December 1999; accepted 10 February 2000.

Supported by the Consortium for Risk Evaluation with Stakeholder Participation (CRESP) through the Department of Energy cooperative agreement (AI number DE-FC01-95EW55084), by the National Institute of Environmental Health Sciences (ESO 5022), the Environmental and Occupational Health Sciences Institute, and Department of Energy Financial Assistance Award DE-FCO9-96SR18546 to the University of Georgia. This research was conducted under Rutgers University protocol 97-017. We thank C. S. Boring for help with field collection; M. McMahon, B. Buckley, W. Johnson, and T. Shukla for laboratory assistance in the Chemical Analysis Laboratory of EOSHI; Pooja Makhijani for laboratory assistance in the Flow Cytometry Laboratory; and B. D. Goldstein, E. Faustman, J. Moore, and C. Powers for valuable comments on the research or manuscript.

Address correspondence to Dr. Joanna Burger, Division of Life Sciences, 604 Allison Road, Piscataway, NJ 08854-8082, USA. E-mail: burger@biology.rutgers.edu 
better understand which metals contribute to the induction of metallothionein, principle component analysis (PCA) was performed. The first three principle components explained $78 \%$ of the variance, with highest loadings being from mercury and radiocesium. Metallothionein levels did not correlate well with the principal components from the metals and radiocesium, while autofluorescent background levels tended to correlate better.

The ability to assess the presence and severity of environmental hazards is critical to protecting the health of humans and other organisms, as well as ecosystem structure and function. Increasingly, it is necessary to develop biomonitoring tools that can be used to assess the health of ecosystems and their components and to provide early warnings for human health concerns (Ratcliffe et al., 1996). One aspect of an animal's well-being that requires monitoring is contaminant loads, including heavy metals, radionuclides, organochlorines, and other toxics.

To assess the levels and effects of contaminants in organisms, it is customary to select a suite of indicators for individuals, populations, species, and community effects (Hunsaker et al., 1990; NRC, 1991, 1993; Peakall, 1992; Linthurst et al., 1995). Information from indicator species can be used (1) in routine biomonitoring programs as early warnings of potential human health problems, (2) to make decisions about possible cleanup, and (3) to evaluate the success of past remediation or efficacy of responsibilities for hazardous wastes. More recently, the importance of selecting indicators that can be used to assess both ecosystem health and human health has been noted (Burger et al., 1997, 1998). Ideally, information about indicator species could be used to assess adverse effects to the species themselves, to other components of the ecosystem, and to humans.

Risk assessment for humans and other animals requires in-depth information about contaminant loads and actual or potential exposure, yet it is often costly and time-consuming to analyze tissues for a wide spectrum of contaminants over a large spatial scale. It is therefore helpful to develop endpoints or biomarkers of exposure to screen for specific contaminants. If such a biomarker indicates exposure, then more detailed studies to identify and quantify the particular contaminants present can be initiated. Such a procedure could have the advantage of providing a rapid assessment of animals from a large geographical area, followed by in-depth studies of contaminant loads in animals from those locations identified by the biomarker.

In this article the relationship between metallothioneins and concentrations of several metals and metalloid elements in the liver tissue of raccoons (Procyon lotor) from the Department of Energy's Savannah River Site (SRS) near Aiken, SC, was examined to determine the applicability of metallothioneins as an initial screening device for exposure assessment in mammals. While metallothionein in mammals is under coordinated regulation by glucocorticoid hormones, cytokines, and metals, other factors can also influence metallothionein induction. SRS is a former nuclear 
production and research facility. It was of particular interest to determine what elements (or combinations of elements) accounted for the variability in metallothioneins in liver tissue.

Metallothioneins (MT) are low-molecular-weight, sulfhydryl-rich proteins that serve a variety of metal binding and transport functions. Some MT are rapidly induced in response to a range of environmental agents such as heavy metals, radiation, or oxidizing chemicals (Bauman et al., 1991). MT and other metalloproteins have been identified in a wide range of vertebrates including mammals (Foulkes, 1993), birds (Stewart et al., 1996), and fish (Hamza-Chaffai et al., 1997; Hamilton \& Mehrle, 1996), as well as invertebrates (Lobel \& Payne, 1984). The antioxidant and metalsequestering abilities of these proteins function to attenuate cellular damage by toxic agents (Miura et al., 1997). Since induction of MT expression is a major component of the stress response, it can be used as an indicator of exposure to chemical, radiological, or environmental stresses. Other factors can also affect MT induction, including temperature and reproductive state, as well as copper and zinc homeostasis (Bauman et al., 1991). In this study, flow cytometry was used to determine the relative cellular levels of MT (Yurkow \& Makhijani, 1998) in the livers of raccoons from SRS.

The raccoon is ideal for development as a bioindicator species because it is almost ubiquitous in the United States (collecting is not a problem); it is relatively high on the food chain and eats a wide variety of foods. In many suburban areas the population of raccoons has reached nuisance proportions. Although males can move several kilometers or more over the course of a few days, raccoons are usually relatively sedentary (nonmigratory), and therefore, contaminant concentrations in their tissues represent local exposure. Further, since in many areas raccoons carry rabies, collections allow for monitoring of rates of rabies at the same time. All 45 randomly selected animals were negative for rabies. Moreover, in some parts of the United States, including around the SRS, raccoons are eaten by humans and their companion animals (SCDHEC, 1996a; Burger, in press).

There has been extensive research on patterns of radiocesium $\left({ }^{137} \mathrm{Cs}\right)$ contamination in tissues of animals from the SRS (Potter et al., 1989; Brisbin, 1993; Burger et al., 1997; Kennamer et al., 1998; Burger \& Gibbons, 1998), but most heavy metals as well as selenium and arsenic have not been examined previously in the resident biota. This research was partially initiated to understand the exposure of wildlife residing in SRS to a suite of contaminants.

The research reported in this article is part of a larger project undertaken by the Consortium for Risk Evaluation with Stakeholder Participation (CRESP) and the Savannah River Ecology Laboratory to understand both the patterns of ${ }^{137} \mathrm{Cs}$ and metals in raccoons, and to develop bioindicators of exposure suitable for other species and other sites that are cost-effective and meaningful in terms of human and ecological health. Because of the potential for contaminated raccoons to wander off-site, at SRS and else- 
where, as well as the possibility of poaching on-site, development of a biomarker of exposure is particularly important. Further descriptions of ${ }^{137} \mathrm{Cs}$ and mercury contamination in a larger sample of raccoons are reported separately (Gaines et al., 2000; Lord, 1999).

\section{STUDY AREA AND METHODS}

\section{Study Area}

The Savannah River Site (SRS) is a $780-\mathrm{km}^{2}$ former nuclear production and research facility of the U.S. Department of Energy, located in westcentral South Carolina $\left(33.1^{\circ} \mathrm{N}, 81.3^{\circ} \mathrm{W}\right)$. The vegetation communities on SRS are typical of the Upper Coastal Plain of South Carolina, and are described in detail by Workman and McLeod (1990). The SRS is bounded on the southwest side by the Savannah River, which was used as a source of cooling water for operating production reactors. As a result of the research and nuclear production activities of SRS, some areas have been contaminated with radionuclides and metals, while others were little, if at all, affected by nuclear production and disposal activities (Kennamer et al., 1998).

Since raccoons generally live in habitats that include wetlands where they obtain much of their food (Burger, 1999), habitats were selected accordingly. Raccoons were collected at three off-site reference locations and at five study sites on SRS (Figure 1). The comparison of ${ }^{137} \mathrm{Cs}$ and metal levels in on-site versus off-site raccoons is presented in separate papers (Gaines et al., 2000). For this study animals from all sites were treated together. The SRS sites were chosen to include some sites contaminated with ${ }^{137} \mathrm{Cs}$ and other radionuclides (Pond B, Steel Creek), sites contaminated with metals (near a coal-fired power plant), and sites that are normally considered reference sites (Dry Bay, Upper Three Runs Creek) (Davis \& Janecek, 1997). Off-site locations were public hunting grounds located $8 \mathrm{~km}$ west-northwest of the town of Jackson, SC, $15 \mathrm{~km}$ northwest of SRS and 3 $\mathrm{km}$ south of SRS (Figure 1). Pond B, an on-site trapping location, received cooling water discharged from the R Reactor, which was shut down in 1964, and it was contaminated with ${ }^{137} \mathrm{Cs}$ from reactor fuel elements that leaked during storage (Whicker et al., 1990). Effluent (purge water containing ${ }^{137} \mathrm{Cs}$ ) from two production reactors was discharged into Steel Creek. In both water systems, the bioaccumulation of ${ }^{137} \mathrm{Cs}$ in resident plants and animals has been demonstrated (Garten et al., 1975; Brisbin et al., 1989; Whicker et al., 1990). Contaminants in the coal ash settling basins include arsenic, cadmium, chromium, copper, and selenium (McCloskey \& Newman, 1995; Rowe et al., 1998); some of these have migrated into the adjacent Beaver Dam Creek, and into the Savannah River (Carlson \& Adriano, 1993).

Dry Bay ( 5 ha), a Carolina bay that has a seasonally variable water level (Semlitsch et al., 1996), and Upper Three Runs have been used as 


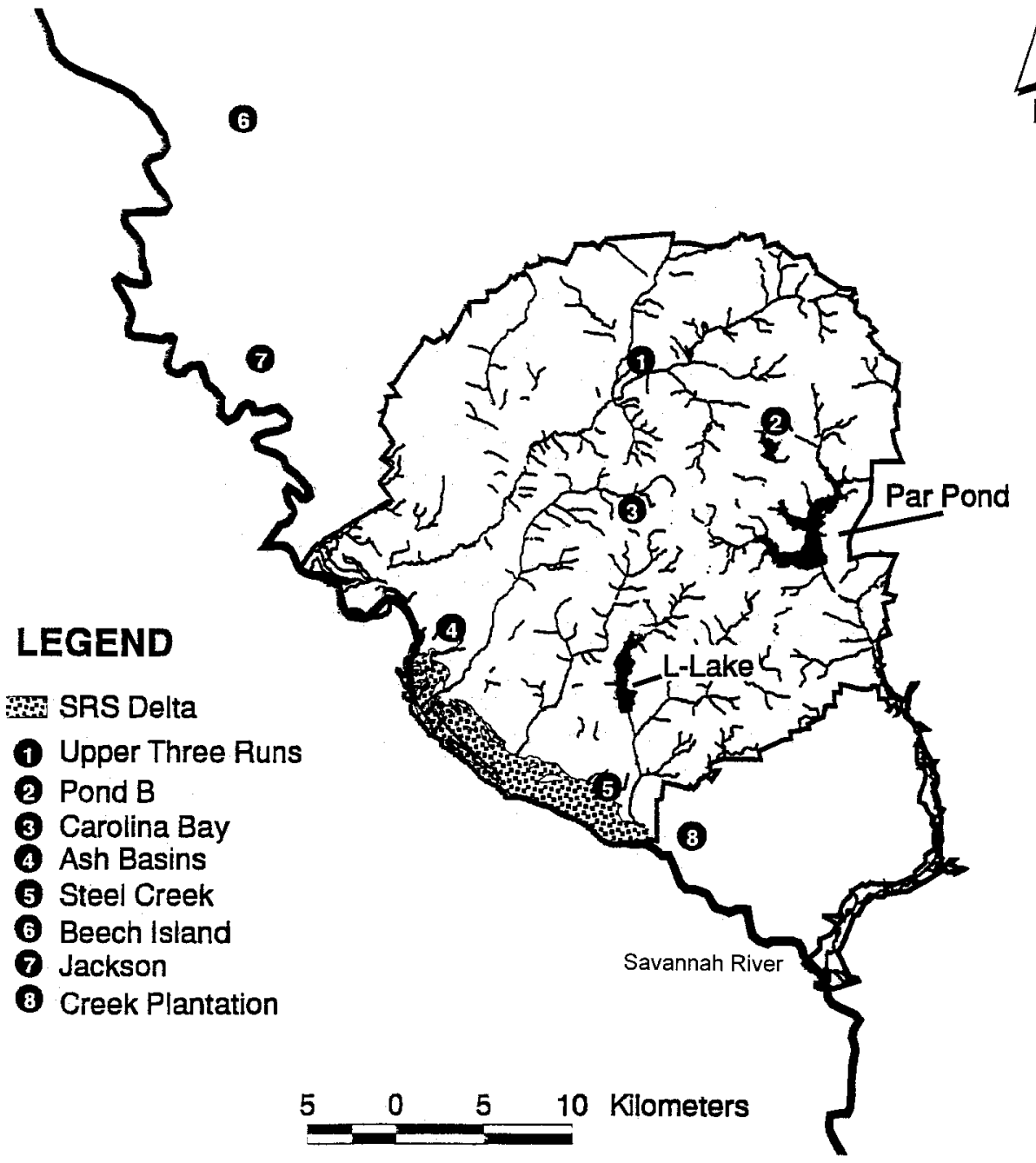

FIGURE 1. Map of the Savannah River Site showing the locations where raccoons were collected.

reference sites for other SRS studies, and they have received little impact from SRS operations (Davis \& Janecek, 1997). The off-site raccoons were collected in lowland, swampy, public lands where raccoons are hunted. More detailed descriptions of the study sites have been provided elsewhere (Gaines et al., 2000).

\section{Raccoon Trapping and Specimen Collection}

Under appropriate state permits and university protocols, 80 male raccoons were collected from the SRS and off-site locations between November 1996 and June 1997 as part of a larger study of contaminants on-site and off-site in this species. A small number of females were collected off- 
site by hunters for the larger study; however, there were no significant gender differences for contaminants. Raccoons were collected with Hava-hart type live traps using canned sardines and a variety of other baits. Only male raccoons were collected to reduce effects on reproduction, to avoid collecting pregnant females or those with young, and to reduce variations due to gender. For this paper, a subset of 47 raccoons selected randomly from the 80 collected, with a nested design that included onsite $(n=35)$ and off-site animals $(n=12)$, was examined.

Raccoons were shot under approved protocols, weighed, and dissected immediately. Livers were removed, divided for contaminant and metallothionein studies, and frozen for transportation to the Environmental and Occupational Health Sciences Institute in Piscataway, NJ.

\section{Metal and ${ }^{137}$ Cs Determinations}

In the laboratory, liver tissue $(0.5 \mathrm{~g})$ was digested in Ultrex ultrapure nitric acid in a microwave (MD 2000 CEM), using a digestion protocol of 3 stages of $10 \mathrm{~min}$ each under 50, 100, and $150 \mathrm{lb} / \mathrm{in}^{2}$ (3.5, 7.0, and 10.5 $\mathrm{kg} / \mathrm{cm}^{2}$ ) at $70 \%$ power. Digested samples were subsequently diluted in $100 \mathrm{ml}$ deionized water.

Except for ${ }^{137} \mathrm{Cs}$, the elements (arsenic, cadmium, chromium, cobalt, copper, lead, manganese, mercury, selenium, silver, strontium, thallium, and vanadium) were analyzed by inductively coupled plasma mass spectroscopy (ICPMS). All concentrations in liver are expressed in parts per million $(\mu \mathrm{g} / \mathrm{g})$ on wet weights obtained from frozen specimens. Detection limits were $0.005 \mathrm{ppm}(5 \mathrm{ng} / \mathrm{g})$, except for mercury, which was 0.0002 ppm. All specimens were run in batches that included a standard calibration curve and spiked specimens. On the ICPMS the accepted recoveries for spikes ranged from $90 \%$ to $110 \%$. The accepted recovery for mercury was $80 \%$ to $120 \%$. Recoveries that were not within this range were rerun. Further quality control included analysis of a standard material (NIST Hg standard, and NIST AB for all other metals) with known concentrations, and blind runs of duplicate samples during the analysis for each metal. Blind replicates that differed by more than $15 \%$ were reanalyzed.

Radiocesium in liver tissue was determined using a Packard AutoGamma A5530 counting system with a $7.62-\mathrm{cm}$ thallium-activated NAI crystal of through-hole design and a counting window of 550-760 keV. Counting time per sample was $60 \mathrm{~min}$ for samples from contaminated areas and 500 min for those from control areas. ${ }^{137} \mathrm{Cs}$ content is reported in becquerels per gram wet weight $(\mathrm{Bq} / \mathrm{g} ; 1 \mathrm{~Bq}=27 \mathrm{pCi})$. To estimate radioactivity per wet mass $(\mathrm{Bq} / \mathrm{g})$, sample gross count rates were adjusted for background count rates, and we compared the adjusted count rates of samples to similarly adjusted count rates of aqueous standards approximating the sample height and containing known quantities of ${ }^{137} \mathrm{Cs}$. The minimum detectable concentrations (MDC) were calculated following procedures described by Currie (1968). Radiocesium levels of all off-site 
raccoon liver tissues were below their respective MDCs, but 58\% of livers from on-site noncontaminated areas and $100 \%$ of those from contaminated areas contained ${ }^{137} \mathrm{Cs}$ above their MDCs. Other details concerning radionuclide analysis can be found in Gaines et al. (2000).

\section{Flow Cytometric Determination of Cellular Metallothionein}

Small sections of paraformaldehyde-fixed raccoon livers were transferred to a Dounce tissue grinder (Wheaton catalog number 357542) and subjected to 25 strokes using a type B pestle. The resulting cell suspensions were passed through a nylon mesh $(60 \mu \mathrm{m}$ pore size), washed with $3 \mathrm{ml}$ phosphate buffer solution (PBS), resuspended in $70 \%$ ethanol, and stored $\left(-20^{\circ} \mathrm{C}\right)$ for up to 6 mo prior to staining (Yurkow \& Makhijani, 1998).

For MT staining, the samples were centrifuged $(800 \times \mathrm{g}$, $5 \mathrm{~min})$, the resulting supernatants were aspirated, and the cells were resuspended in a permeabilization buffer ( $1 \mathrm{ml}$ ) containing 3\% fetal bovine serum (FBS), $0.1 \%$ sodium azide, and $0.1 \%$ saponin in PBS for $1 \mathrm{~h}$ at $25^{\circ} \mathrm{C}$. The hepatocytes were then washed $(2 \times 3 \mathrm{ml})$ with staining buffer $(3 \% \mathrm{FBS}, 0.1 \%$ sodium azide in PBS) and again centrifuged $(800 \times g$, $5 \mathrm{~min})$. The resulting supernatants were aspirated and the cells were incubated with MT-specific antibody (1 mg/105 cells/200 ml, catalog number AXL762M, clone E9, Accurate Chemical and Scientific Corporation) for $1 \mathrm{~h}$ at $25^{\circ} \mathrm{C}$. Following treatment with the primary antibody, the cells were washed $(3 \times 2 \mathrm{ml})$ with staining buffer and incubated for $1 \mathrm{~h}\left(25^{\circ} \mathrm{C}\right)$ with a fluorescein isothiocyanate-conjugated secondary antibody (Sigma). Samples probed with an irrelevant (isotypic) antibody (clone X40, IgG1, Becton Dickinson) in conjunction with the fluorescein-conjugated secondary antibody served as staining controls. The cells were then washed with $3 \mathrm{ml}$ staining buffer, resuspended in $500 \mathrm{ml} \mathrm{PBS}$, and the mean relative fluorescent intensity was determined using an EPICS Profile flow cytometer (Coulter Electronics, Inc., Hialeah, FL). The excitation wave length was $488 \mathrm{~nm}$, and the emission was read at $520 \mathrm{~nm}$. The fluorescent intensity was on a relative (unit-free) scale. Cellular debris was excluded from fluorescence analysis using forward angle and $90^{\circ}$ light scatter (log) gates (Yurkow \& Makhijani, 1998). The histograms generated in these experiments were analyzed using EPICS Workstation software (Version 4.01; Coulter Electronics, Inc.). Further details on calibration and validation with appropriate standards are provided by Yurkow and Makhijani (1998) and Yurkow and DeCoste (1999).

\section{Statistical Methods}

Distributions of all data variables were examined using Shapiro-Wilkes statistics (PROC UNIVARIATE, version 6.12; SAS Institute, Inc., 1988). Tests of hypotheses that these data were random samples from normal distributions were all rejected ( $p<.05$, except for raccoon body weight), and stem-and-leaf plots indicated that distributions approach log-normal. All statistical tests were performed on the log-transformed values except 
for body weight. All metal and ${ }^{137} \mathrm{Cs}$ levels, including those below the detection limit, were used in the analysis. Since one untransformed ${ }^{137} \mathrm{Cs}$ value was negative (which resulted from the sample count rate being below the background count rate) and some values were $0,{ }^{137} \mathrm{Cs}$ data (addition of $0.01 \mathrm{~Bq} / \mathrm{g}$ ) were scaled to prevent errors in the log-transformations. No other variables had negative or zero values.

Pearson's correlations were used to determine how each metal, ${ }^{137} \mathrm{Cs}$, and body weight related to the metallothionein and the autofluorescent background levels. This relationship was further examined by performing multiple linear regressions on all metals, ${ }^{137} \mathrm{Cs}$, and body weight using metallothionein and the autofluorescent background levels as separate dependent variables. Our initial objective was to examine the levels of metallothionein as function of the independent variables; examination of autofluorescent background was examined a posteriori. A principal component analysis (PCA) was used to explore the underlying covariation structure of the metal and ${ }^{137} \mathrm{Cs}$ data. A covariance matrix was used in the PCA to preserve the scale relationship of the variance differences among the metals. Each principle component was then used in a Pearson's correlation to explore how each component related to the metallothionein and the autofluorescent background values.

\section{RESULTS}

The mean body mass for the raccoons was $4.4 \mathrm{~kg}$ (range $1.7-7.0 \mathrm{~kg}$ ). The weights did not delineate distinct age categories (i.e., adult and immature animals).

\section{Elemental Analyses}

Overall, the concentrations of copper were very high; manganese, mercury and selenium were intermediate; and cadmium, chromium, lead, and vanadium were low (Table 1 and Figure 2). For all metals, distributions were not normal, and medians were correspondingly lower than the means. Arsenic, cobalt, silver, thallium, and tin were below the detection limit for all samples. Radiocesium levels were also relatively low (Table 1), with a maximum of $0.124 \mathrm{~Bq}{ }^{137} \mathrm{Cs} / \mathrm{g}$.

\section{Metallothionein Levels}

Levels of metallothionein ranged from 0 to 26 (relative mean fluorescence intensity) with a mean of 4.4 (Figure 3). Although the present study was not designed to examine locational differences, a posteriori, there was a significant difference in metallothionein levels on-site (mean $=5.0 \pm 0.8$ ) versus off-site $($ mean $=2.2 \pm 0.5, t$-test for unequal variances $=2.8, p<$ .008).

Metallothionein levels significantly correlated with mercury, copper, and selenium. Autofluorescent background significantly correlated with 
TABLE 1. Concentrations of Elemental Contaminants in Raccoon Liver from Savannah River Site, and Pearson's Correlations with Metallothionein and Autofluorescent Background

\begin{tabular}{|c|c|c|c|c|c|}
\hline \multirow[b]{2}{*}{ Contaminant } & \multirow[b]{2}{*}{ Mean \pm SE } & \multicolumn{2}{|c|}{ Metallothionein } & \multicolumn{2}{|c|}{$\begin{array}{c}\text { Autofluorescent } \\
\text { background }\end{array}$} \\
\hline & & $\begin{array}{l}\text { Correlation } \\
\text { coefficient }\end{array}$ & $p$ Value & $\begin{array}{l}\text { Correlation } \\
\text { coefficient }\end{array}$ & $p$ Value \\
\hline Mercury & $1.33 \pm 0.18$ & .313 & $.032^{a}$ & .554 & $.000^{a}$ \\
\hline Cesium-137 & $0.08 \pm 0.02$ & .167 & .262 & .384 & $.008^{a}$ \\
\hline Vanadium & $0.53 \pm 0.05$ & -.069 & .647 & -.169 & .256 \\
\hline Chromium & $0.35 \pm 0.02$ & -.201 & .175 & .062 & .677 \\
\hline Manganese & $4.84 \pm 0.18$ & .050 & .741 & -.153 & .303 \\
\hline Copper & $12.86 \pm 0.77$ & .301 & $.040^{a}$ & -.105 & .484 \\
\hline Selenium & $2.34 \pm 0.13$ & .298 & $.042^{a}$ & .537 & $.000^{a}$ \\
\hline Strontium & $0.21 \pm 0.01$ & -.091 & .543 & -.375 & $.010^{a}$ \\
\hline Cadmium & $0.51 \pm 0.05$ & .030 & .843 & .206 & .165 \\
\hline Lead & $0.48 \pm 0.06$ & .049 & .745 & .211 & .154 \\
\hline Body mass (kg) & $4.42 \pm 0.16$ & -.033 & .828 & .069 & .645 \\
\hline Metallothionein & $4.30 \pm 0.64$ & & & & \\
\hline $\begin{array}{c}\text { Autofluorescent } \\
\text { background }\end{array}$ & $20.92 \pm 0.86$ & & & & \\
\hline
\end{tabular}

Note. Given are the means \pm standard errors of each contaminant. Concentrations are in $\mu \mathrm{g} / \mathrm{g}$ (ppm, wet weight), except for ${ }^{137} \mathrm{Cs}$, which is in bequerels $\mathrm{Bq} / \mathrm{g}$ wet weight.

${ }^{a}$ Significant at .05 level.

mercury, ${ }^{137} \mathrm{Cs}$, selenium, and strontium (Table 1). The relationship of the metallothionein levels with the metals, ${ }^{137} \mathrm{Cs}$, and body weight was not significant. However, this relationship was significant for the autofluorescent background levels $\left(F_{11,35}=6.332, p=.0001\right)$. Further, metallothionein levels did not correlate well with the principal components from the metals and ${ }^{137} \mathrm{Cs}$, while autofluorescent background levels tended to correlate better (PC loadings are shown in Table 2; correlations are shown in Table 3).

\section{DISCUSSION}

\section{Methodological Considerations}

There are some methodological concerns regarding studies of metallothionein. Investigative approaches based on the extraction of metallothionein might bias the results low, because of oxidation and degradation. Moreover, metals are distributed differentially among organs, and hence the liver concentrations might not adequately reflect the role of the metal in the body. Each is discussed briefly here.

Cognizant of the first concern, the present study was not based on extracting metallothionein from the raccoon hepatocytes, which might re- 


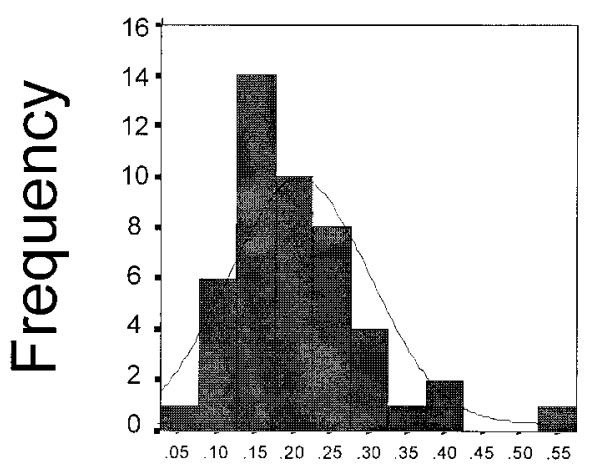

Strontium88 (ppm) $\begin{aligned} & \text { Std Dev }=.09 \\ & M=a n=.21 \\ & N=47.00\end{aligned}$

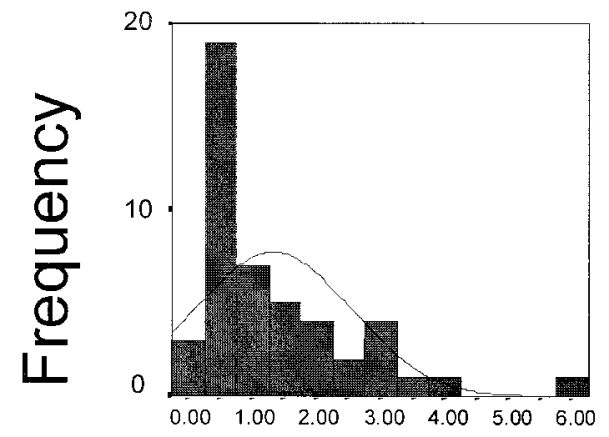

Mercury (ppm) $\begin{aligned} & \text { Std. Dev }=1.21 \\ & \text { Mean }=1.33 \\ & \mathrm{~N}=47.00\end{aligned}$

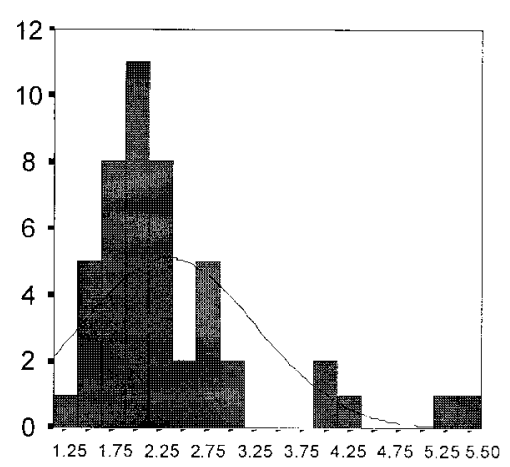

Std Dev $=.91$ Selenium (ppm) $\begin{aligned} & \text { Mean }=2.34 \\ & \mathrm{~N}=47.00\end{aligned}$

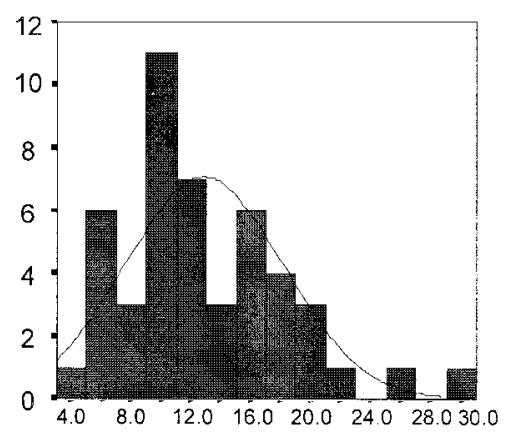

Copper $(\mathrm{ppm}) \begin{aligned} & \begin{array}{l}\text { Std. Dev }=5.29 \\ \text { Mean }=12.9 \\ \mathrm{~N}=47.00\end{array} \\ & \text {. }\end{aligned}$

FIGURE 2. Distribution of concentrations (ppm, wet weight) of copper, mercury, strontium, and selenium in raccoon livers from on and around the U.S. Department of Energy's Savannah River Site.

sult in sample biases. Rather, relative cellular levels of metallothionein were determined using flow cytometry and a fluorescent (metallothionein-specific) antibody. For this analysis a single-cell suspension of hepatocytes was generated from formalin-fixed raccoon livers, and the lipid contents of the liberated cells were removed using standard detergent-containing buffers. These mild detergent buffers do not remove cellular proteins (i.e., metallothionein) or DNAVRNA from the fixed cells. Following this process, the relative metallothionein content of the liberated cells was determined using a fluorescent metallothionein-specific antibody and flow cytometry. In this analysis, cellular fluorescence reflects relative metallothionein content of the cells. The antibody that was employed for the studies (i.e., generated from the E9 hybridoma) is the most commonly used metallothionein antibody. Originally generated using paraformaldehyde-fixed equine metallothionein as antigen, this antibody has been shown to quantitatively detect metallothionein from diverse species (i.e., from earthworms to humans). Further- 


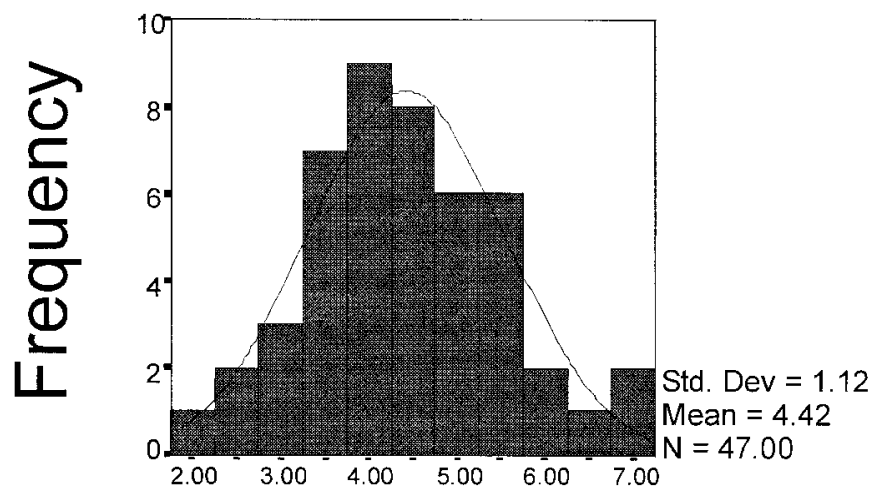

Body weight $(\mathrm{kg})$

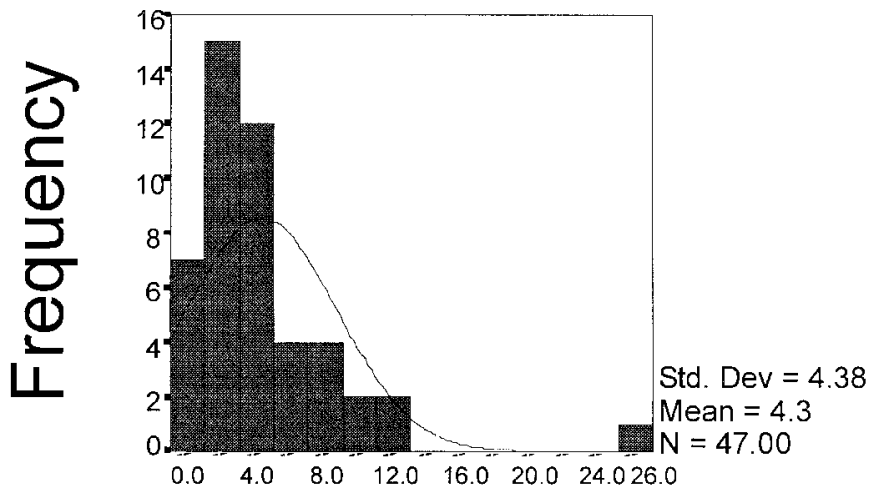

Metallothionein

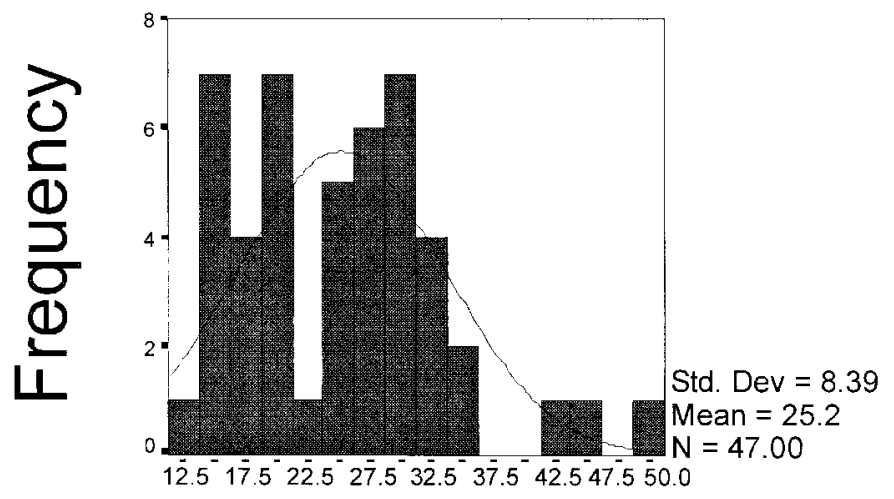

\section{Metallothionein Background}

FIGURE 3. Distribution of weights of raccoons, metallothionein level, and background cellular autofluorescence (relative fluorescent intensity on a unit free scale). 


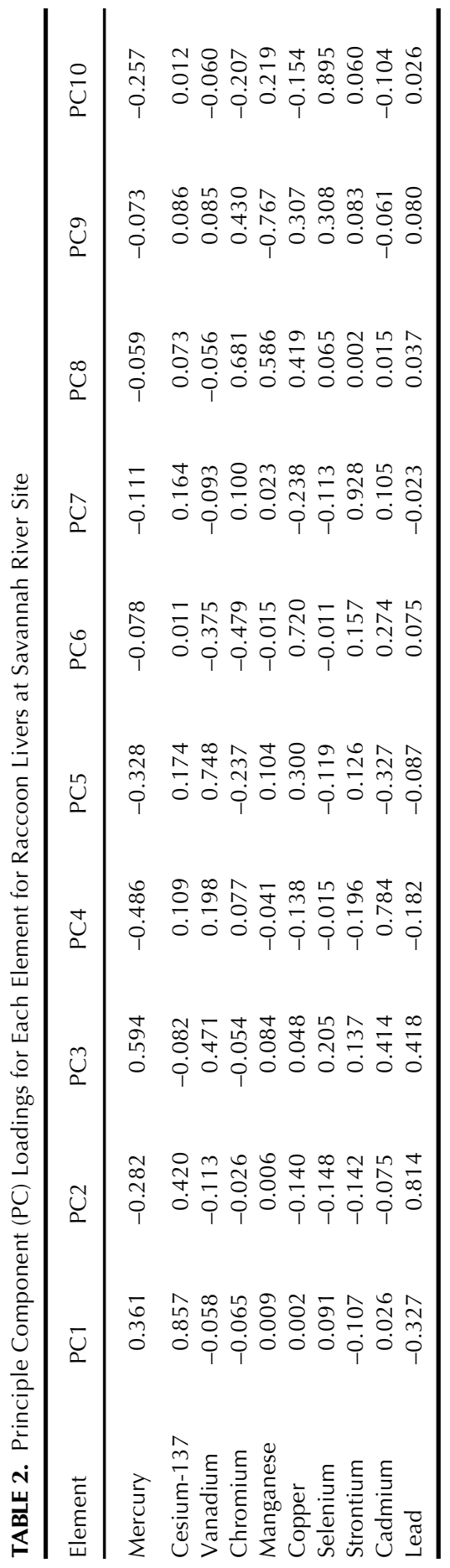


TABLE 3. Pearson's Correlation of Metallothionein and Autofluorescent Background for Raccoon Livers at Savannah River Site With Each Principle Component (PC)

\begin{tabular}{|c|c|c|c|c|c|c|}
\hline \multirow[b]{2}{*}{ Component } & \multirow[b]{2}{*}{ Eigenvalue } & \multirow[b]{2}{*}{$\begin{array}{l}\text { Cumulative } \\
\% \text { variance }\end{array}$} & \multicolumn{2}{|c|}{ Metallothionein } & \multicolumn{2}{|c|}{$\begin{array}{c}\text { Autofluorescent } \\
\text { background }\end{array}$} \\
\hline & & & $\begin{array}{l}\text { Correlation } \\
\text { coefficient }\end{array}$ & $p$ Value & $\begin{array}{l}\text { Correlation } \\
\text { coefficient }\end{array}$ & $p$ Value \\
\hline PC1 & 2.049 & $41.1 \%$ & .203 & .172 & .501 & .000 \\
\hline PC2 & 1.040 & $61.9 \%$ & .034 & .819 & -.097 & .518 \\
\hline PC3 & 0.803 & $78.0 \%$ & .199 & .180 & .188 & .206 \\
\hline PC4 & 0.396 & $85.9 \%$ & -.203 & .172 & -.027 & .856 \\
\hline PC5 & 0.256 & $91.1 \%$ & -.111 & .459 & -.470 & $.001^{a}$ \\
\hline PC6 & 0.173 & $94.5 \%$ & .288 & $.049^{a}$ & -.097 & .518 \\
\hline PC7 & 0.122 & $97.0 \%$ & -.209 & .159 & -.290 & $.048^{a}$ \\
\hline PC8 & 0.077 & $98.5 \%$ & .083 & .578 & -.026 & .862 \\
\hline PC9 & 0.043 & $99.4 \%$ & .116 & .439 & .190 & .202 \\
\hline PC10 & 0.029 & $100.0 \%$ & .100 & .504 & .058 & .699 \\
\hline
\end{tabular}

Note. The eigenvalue and cumulative percent variance are presented with each component.

${ }^{a}$ Significant at .05 level.

more, this antibody has been shown to quantitatively detect MT in fixed tissue that have been embedded in archived paraffin blocks for several years. The epitope that is recognized by the antibody is known to be stable and not subject to modification by oxidants (Suzuki, 1992). Age of the liver samples would not have influenced the results of the experiments with respect to metallothionein determination.

Secondly, it has recently, been demonstrated using wild-type and metallothionein knockout mice that there is a complex relationship between metallothionein expression and the tissue distribution of heavy metals. For example, the results of some of these studies indicate that the distribution of cadmium in specific tissues may be regulated by a cellular process that parallels (but is independent of) metallothionein expression. These results also indicate that our previous assumptions concerning the importance of metallothionein in sequestering metals in specific tissues following toxic exposure were oversimplified. In light of our recent increased understanding of this phenomenon, it is possible that MT expression and tissue metal concentration may not always be correlated, especially following chronic (environmental) exposure to a variety of heavy metals. An extensive study to further characterize the relationship between metal concentrations and metallothionein expression in specific tissues is clearly needed.

\section{Raccoons as Bioindicators}

Developing methods to rapidly assess potential contamination in raccoon tissue is important as a measure of potential harm not only to the raccoons themselves and their ecosystem through food-chain effects, but to 
human consumers as well. In much of the southeastern United States, including South Carolina, raccoons are important because they are trapped for fur and hunted for sport and food (SCDHEC, 1996b). Raccoon hunting is increasing in popularity, particularly among young hunters; in the last $10 \mathrm{yr}$ participation in raccoon-hunting field trials has doubled (SCDHEC, 1996b). While state natural resource departments frequently monitor hunting activities, there is little direct information on consumption patterns, or the risk to humans of consuming raccoon meat. However, in a survey of attendees at a local sportsmen's show (Palmetto Sportsmen's Classic in Columbia, SC), 10\% of the people reported eating raccoon (Burger, in press).

The risk to humans and other consumers of raccoons is a function of contaminant levels and exposure. Thus the question of potential exposure is key to evaluating the hazards associated with contaminated raccoons on a site like the SRS. While contaminated raccoons can clearly pose a potential threat to other predatory animals (e.g., panthers, Felis concolor, which do not occur at SRS; Roelke et al., 1991), the potential risk to humans is only of interest if the raccoons are hunted on-site or if they wander off-site where they can be shot. There are both public and private hunting grounds adjacent to the SRS site, so the question of movement of animals off-site is important to determining the risk to humans.

In some places raccoons can move an average of nearly $200 \mathrm{~m} / \mathrm{h}$, and radiotelemetry studies indicate that some males move $5 \mathrm{~km}$ in a day (Urban, 1970), although raccoons in suburban areas typically move much shorter distances (Hoffmann \& Gottschang, 1977). The diameter of the raccoon home range is generally $4-10 \mathrm{~km}$ (Fritzell, 1978, 1997), and at SRS, some of the contaminated cooling ponds and streams are less than $10 \mathrm{~km}$ from the boundary of the site, indicating potential off-site movement of raccoons frequenting these areas. At SRS, raccoons that are equipped with radios normally remain within a $2-\mathrm{km}$ radius of their initial trapping location (S. Boring, personal communication), but this distance increases during the mating season. This would mean, however, that some raccoons move onand off-site. Because of the potential for dispersal off-site, it is especially useful to have biomonitoring tools to assess the potential hazard from contaminated raccoons to humans and other components of ecosystems.

\section{Metallothionein as a Biomarker for Metals}

The results of this study indicate that, under some circumstances, assessing induction of metallothionein levels in raccoon tissues may be a more rapid and cost-effective method for screening certain metals (mercury, copper, and selenium), compared to chemical analysis, although we did not demonstrate a dose-dependent response, as suggested by Stegeman et al. (1992) as a criterion. Metallothionein induction offers the advantage of being a biomarker of effect (induction) as well as exposure. If preliminary results indicate elevated MT levels, however, chemical analysis would be required to obtain more detailed information. When raccoons exhibit high 
levels of metallothionein, it indicates a need for further measurement of the range of contaminants to determine the specific element of concern, as well as oxidizing chemicals and radiation.

In an appropriately equipped and staffed laboratory, it is less expensive to analyze for MT than for a large number of metals, assuming that all necessary instrumentation is available. Labor and supply costs for the metallothionein analysis alone were approximately $\$ 1200$, while supply costs and labor only for the metal analysis were $\$ 5400$ for the 47 samples. Moreover, the time devoted to tissue preparation before chemical analysis and data interpretation after analysis was much greater for chemical analysis than for metallothionein analysis.

Data suggest that metallothionein levels can be potentially used as a screening device, although considerably more studies are needed with a wide range of wildlife species before the method can be used broadly. In this study, data showed significant correlations between metallothionein levels and the concentrations of selenium, copper, and mercury in liver, but not the other metals. Several elements (arsenic, cobalt, silver, thallium, and tin) were consistently below detection levels. The other metals showed weak positive correlations with MT and autofluorescence. The lack of a relationship was due partly to relatively low levels and range of values of several of the metals, but it could also be truly indicative of no relationship. In future studies, zinc should be examined because it clearly induces metallothionein (Yurkow \& DeCoste, 1999).

Finally, this study was not designed to determine whether metals and metallothioneins varied as a function of age, gender, seasonality, or reproductive state. Our objective was merely to determine whether there were relationships between metallothionein and metals in a population of raccoons.

\section{Relationship Between Metallothionein, Background, and Contaminants}

Metallothionein induction is both a specific response to certain metals and a nonspecific response to a variety of environmental stresses such as heavy metals, oxidizing chemicals, and radiation (Bauman et al., 1991). Metallothioneins function, in part, to attenuate cellular damage that is induced by the chemical agents, particularly metals (Miura et al., 1997). Thus metallothioneins can be used as a biomarker of exposure. MT induction is one of the specific effects of certain metals, and it is thus a marker of effect which enhances its utility (McMenamin \& Goldstein, 1998). Due to the nonspecific nature of metallothionein induction, more detailed studies of the relationship between different environmental contaminants and MT are required to establish patterns.

In this study, metallothionein levels were positively and significantly correlated with concentrations of copper, selenium, and mercury. There was also a positive correlation between mercury and selenium. These elements can be negatively correlated in birds (Burger \& Gochfeld, 1996), 
amphibians (Burger \& Snodgrass, 1998), and mammals (Koeman et al., 1973), but are positively correlated in some marine mammals (Koeman et al., 1973). Selenium is well known to protect against the toxic effects of mercury; several investigations with vertebrates showed that animals with otherwise lethal or sublethal levels of mercury in their livers showed few or no symptoms of mercury poisoning when selenium was supplied (Hill, 1974; Parizek et al., 1974; Stoewsand et al., 1974; El-Begearmi et al., 1977).

Surprisingly, a significant relationship between metallothionein levels and concentrations of cadmium (Pearson's $r=.03$ ) was not found. Cadmium is known to induce metallothionein in humans (Yurkow \& Makhijani, 1998; Yurkow \& DeCoste, 1999) and other mammalian cells (Foulkes, 1993). Wahba et al. (1993) showed that selenium treatments enhanced cadmium accumulation in rat tissues, and suggested that selenium prevents acute cadmium toxicity through a mechanism that does not involve induction of metallothionein. Our studies with cadmium, therefore, were inconclusive. This lack was not due either to a lack of range in cadmium concentrations within the raccoon livers $(0.13-1.5 \mathrm{ppm})$, or to unusually low levels. Cadmium levels are usually relatively low in wildlife in nature (Eisler, 1985). The lack of a relationship between cadmium and metallothionein levels in the raccoon livers in this study may reflect important species differences in the MT inducibility by different metals, and this requires more extensive studies with a range of animals. However, it could also reflect the fact that other metals, such as selenium, influence these relationships.

The fact that two of the highest loadings to the first principal component (PC1, which explained $41 \%$ of the variance) were from mercury and ${ }^{137} \mathrm{Cs}$ is not surprising, considering the specific sites where raccoons were trapped. Known ${ }^{137} \mathrm{Cs}$-contaminated sites accounted for $34 \%$ of the raccoons that were used in this analysis. Further, these same sites are associated with cooling reservoirs where mercury has concentrated from water that was pumped from the Savannah River. Although concentrations of mercury in the river are not high, water pumped into the cooling reservoirs to counter loss by evapotranspiration and seepage has led to increased concentrations in the reservoirs over several decades (Sugg et al., 1995). The origins of the mercury are unknown, but much of it probably came from upstream industries that discharged effluent into the river (Sugg et al., 1995). Further, 15\% of the raccoons were from seepage basins that have known elevated levels of other metals. This relationship of mercury and ${ }^{137} \mathrm{Cs}$ may help explain why PC1 correlated with the autofluorescent background levels as well as why they individually correlated with the autofluorescent background levels. Radiation is known to cause DNA strand breakage, and mercury has been suggested to inhibit DNA repair mechanisms (Sugg et al., 1995). Therefore, the autofluorescent background levels may be showing a stress in the organism from these toxicants but in a form that is not fully understood. 
One of the most interesting and unexpected results of this study was the a posteriori finding of a relationship between mercury, selenium, and strontium levels and the level of fluorescent background in liver cells. Throughout the experiment, unstained hepatocytes exhibited high intrinsic fluorescence that varied dramatically among the liver samples. The specific source(s) of this fluorescence has not been identified but could derive from other proteins, cofactors (such as NADPH), or other small molecules. Other investigators have associated the intrinsic fluorescence of cells with specific cellular constituents (i.e., pyrimidines and flavin nucleotides) and metabolic states (Nokubo et al., 1988, 1989; Mayeno et al., 1992; Sugg et al., 1995; Banerjee et al., 1998). Therefore, it is possible that an elevated cellular autofluorescence may be useful as a general bioindicator of exposure to specific chemicals, because autofluorescence may be an indication of the ability to metabolize, excrete, or transport metals in biological systems.

\section{REFERENCES}

Banerjee, B., Miedema, B., and Chandrasekhar, H. R. 1998. Emission spectra of colonic tissue and endogenous fluorophores. Am. J. Med. Sci. 316:220-226.

Bauman, J. W., Liu, J., Liu, L. P., and Klaassen, C. D. 1991. Increase in metallothionein produced by chemicals that induce oxidative stress. Toxicol. Appl. Pharmacol. 110:347-354.

Brisbin, I. L., Jr. 1993. Birds as monitors of radionuclide contamination. In Birds as monitors of environmental change, eds. R. W. Furness and J. J. D. Greenwood, pp. 144-178. London: Chapman \& Hall.

Brisbin, I. L., Jr., Breshars, D. D., Brown, K. L., Ladd, M., Smith, M. H., Smith, M. W., and Towns, A. L. 1989. Relationships between levels of radiocesium in components of terrestrial and aquatic food webs of a contaminated steambed and floodplain community. J. Appl. Ecol. 26:173-182.

Burger, J. 1999. Interactions of animals in towns and cities. Dubuque, IA: Kendall-Hunt.

Burger, J., and Gibbons, J. W. 1998. Trace elements in egg contents and egg shells of slider turtles. Arch. Environ. Contam. Toxicol. 34:382-386.

Burger, J., and Gochfeld, M. 1996. Heavy metal and selenium levels in Franklin's gull (Larus pipixcan) parents and their eggs. Arch. Environ. Contam. Toxicol. 30:487-491.

Burger, J. In press. Gender differences in meal patterns: role of self-caught fish and wild game in meat and fish diets. Environ. Res.

Burger, J., and Snodgrass, J. 1998. Heavy metals in bullfrog (Rana catesbeiana) tadpoles: Effects of depuration before analysis. Environ. Toxicol. Chem. 17:2203-2209.

Burger, J., Kennamer, R. A, Brisbin, I. L., Jr., and Gochfeld, M. 1997. Metal levels in mourning doves from South Carolina: potential hazards to doves and hunters. Environ. Res. 75:173-186.

Burger, J., Kennamer, R. A., Brisbin, I. L., Jr., and Gochfeld, M. 1998. Risk from consuming doves. Risk Anal. 18:563-573.

Carlson, C. L., and Adriano, D. C. 1993. Environmental impacts of coal combustion residues. J. Environ. Qual. 22:227-247.

Currie, L. A. 1968. Limits for qualitative detection and quantitative determination. Anal. Chem. 40: 586-593.

Davis, C. E., and Janecek, L. L. 1997. DOE Research Set-Aside Areas of the Savannah River Site. Publication SRO-NERP-25. Aiken, SC: Savannah River Ecology Laboratory.

El-Begearmi, M. M., Sunde, M., and Ganther, H. E. 1977. A mutual protective effect of mercury and selenium in Japanese quail. Poult. Sci. 56:313-322.

Eisler, R. 1985. Cadmium hazards to fish, wildlife, and invertebrates: A synoptic review. Fish \& Wildlife Service, U.S. Department of the Interior. Hazard Rev. 2. 
Foulkes, E. C. 1993. Metallothionein and glutathione as determinants of cellular retention and extrusion of cadmium and mercury. Life Sci. 52:1617-1620.

Fritzell, E. K. 1978. Aspects of raccoon (Procyon lotor) social organization. Can. J. Zool. 56:260-271.

Fritzell, E. K. 1997. Sexual differences in home ranges in raccoons. J. Mammal. 78:921-931.

Gaines, K. F., Lord, C. G., Boring, C. S., Brisbin, I. L., Jr., Gochfeld, M., and Burger, J. 2000. Raccoons as a potential vector of radionuclide contamination to human food chains from a nuclear industrial site. J. Wildl. Manage. 64:199-208.

Garten, C. T., Jr., Gentry, J. B., Pinder, J. E. III, Sharitz, R. R., and Smith, M. H. 1975. Radiocesium dynamics in a contaminated floodplain ecosystem in the southeastern United States. In Impacts of nuclear releases into the aquatic environment, Vol. SM-198/41, pp. 331-347. Vienna, Austria: International Atomic Energy Agency.

Hamilton, S. J., and Mehrle, P. M. 1996. Metallothionein in fish: Review of its importance in assessing stress from metal contaminants. Trans. Am. Fish Soc. 115:596-609.

Hamza-Chaffai, A., Amiard-Triquet, C., and Abed, A. E. 1997. Metallothionein-like protein: Is it an efficient biomarker of metal contamination? A case study based on fish from the Tunisian coast. Arch. Environ. Contam. Toxicol. 33:53-62.

Hill, C. H. 1974. Reversal of selenium toxicity in chicks by mercury, copper, and cadmium. J. Nutr. 104:593-598.

Hoffmann, C. O., and Gottschang, J. L. 1977. Numbers, distribution, and movement of a raccoon population in a suburban residential community. J. Mammol. 58:623-636.

Hunsaker, C., Carpenter, D., and Messer, J. 1990. Ecological indicators for regional monitoring. Bull. Ecol. Soc. Am. 71:165-172.

Kennamer, R. A., Brisbin, I. L., Jr., McCreedy, C. D., and Burger, J. 1998. Radiocesium in mourning doves: Effects of a contaminated reservoir drawdown and risk to human consumers. J. Wildl. Manage. 62:487-508.

Koeman, J. H., Peeters, W. H. M., Koudstaai-hol, C. H. M., Thoe, P. S., and deBoeij, J. J. M. 1973. Mercury-selenium correlations in marine mammals. Nature 245f:385-386.

Linthurst, R. A., Bourdeau, P., and Tardiff, R. G. 1995. Methods to assess the effects of chemicals on ecosystems. New York: Wiley \& Sons.

Lobel, P. B., and Payne, J. F. 1984. An evaluation of mercury-203 for assessing the induction of metallothionein-like proteins in mussels exposed to cadmium. Bull. Environ. Contam. Toxicol. 33: 144-152.

Lord, C. G. 1999. Mercury in raccoons: Bioindicator of environmental contamination. MS Thesis, Rutgers University, Piscataway, NJ.

Mayeno, A. N., Hamann, K. J., and Gleich, G. J. 1992. Granule-associated flavin adenine dinucleotide (FAD) is responsible for eosinophil autofluorescence. J. Leukocyte Biol. 51:172-175.

McCloskey, J. T., and Newman, M. C. 1995. Sediment preference in the Asiatic clam (Corbicula fluminea) and viparid (Campeloma decisum) as a response to low-level metal and metalloid contamination. Arch. Environ. Contam. Toxicol. 28:195-202.

McMenamin, M. A., and Goldstein, B. D. 1998. Biomarkers in cost-benefit analysis and regulatory control: Lead, asbestos, carbon monoxide and benzene. In Biomarkers: Medical and workplace applications, eds. M. L. Mendelsohn, L. C. Mohr, and J. P. Peeters, pp. 423-434. Washington, DC: Joseph Henry Press.

Miura, T., Muraoka, S., and Ogisio, T. 1997. Antioxidant activity of metallothionein compared with reduced glutathione. Life Sci. 60:301-309.

National Research Council. 1991. Animals as sentinels of environmental health hazards. Washington, DC: National Academy Press.

National Research Council. 1993. Issues in risk assessment. Washington, DC: National Academy Press.

Nokubo, M., Nagy, I., Kitani, K., and Ohta, M. 1988. Characterization of the autofluorescence of rat liver plasma membranes. Biochim. Biophys. Acta 939:441-448.

Nokubo, M., Ohta, M., Kitani, K., and Nagy, I. 1989. Identification of protein-bound riboflavin in rat hepatocyte plasma membrane as a source of autofluorescence. Biochim. Biophys. Acta 981: 303-308. 
Parizek, J., Kalouskova, J., Babicky, A., Bennes, J., and Pavlik, L. 1974. Interactions of selenium with mercury, cadmium, and other toxic metals. Trace Elem. Metab. Anim. 2:119-131.

Peakall, D. B. 1992. Animal markers as pollution indicators. London: Chapman and Hall.

Potter, C. M., Brisbin, I. L., Jr., McDowell, S. G., and Whicker, F. W. 1989. Distribution of ${ }^{137}$ Cs in the American coot (Fulica americana). J. Environ. Radio. 9:105-115.

Ratcliffe, H. E., Swanson, G. M., and Fischer, L. J. 1996. Human exposure to mercury: A critical assessment of the evidence of adverse health effects. J. Toxicol. Environ. Health 49:221-270.

Roelke, M. E. Schultz, D. P., Facemire, C. F., Sundloff, S. F., and Royals, H. E. 1991. Mercury Contamination in Florida Panthers. Report to Florida Panther Technical Subcommittee, Florida Game and Freshwater Fish Commission, Tallahassee, FL.

Rowe, C. L., Kinney, O. M., Nagle, R. D., and Congdon, J. D. 1998. Elevated maintenance costs in an anuran (Rana catesbeiana) exposed to a mixture of trace elements during the embryonic and early larval periods. Physiol. Zool. 71:27-35.

SAS Institute, Inc. 1988. Statistical analysis system: statistics. Cary, NC: SAS Institute, Inc.

Semlitsch, R. D., Scott, D. E., Pechmann, J. H. K., and Gibbons, J. W. 1996. Structure and dynamics of an amphibian community: evidence from a 16-year study of a natural pond. In Long-term studies of vertebrate communities, eds. M. L. Cody and J. Smallwood, pp. 217-248. New York: Academic Press.

South Carolina Department of Natural Resources. 1996a. 1995-96 Commercial fur harvest summary. Furbearer Resources Bull. Fall: 1, 7.

South Carolina Department of Natural Resources. 1996b. The impact of sport raccoon hunting on deer movement and deer hunting success. Furbearer Resources Bull. Fall.

Stegeman, J. J., Brouwer, M., DiGiulio, R. T., Forlin, L., Fowler, B. A., Sanders, B. M., and Van Veld, P. A. 1992. Molecular responses to environmental contamination-Enzyme and protein systems as indicators of chemical exposure and effect. In Biomarkers: Biochemical, physiological and histological markers of anthropogenic stress, eds. R. J. Huggett, R. A. Kimerle, P. A. Mehrle, and H. L. Bergman, pp. 235-335. Chelsea, MI: Lewis.

Stewart, F. M., Furness, R. W., and Monteiro, L. R. 1996. Relationships between heavy metal and metallothionein concentrations in lesser black-backed gulls, Larus fuscus, and Cory's shearwater, Calonectris diomedea. Arch. Environ. Contam. Toxicol. 30:299-305.

Stoewsand, G. S., Bache, C. A., and Lisk, D. J. 1974. Dietary selenium protection of methylmercury intoxication of Japanese quail. Bull. Environ. Contam. Toxicol. 11:152-156.

Sugg, D. W., Chesser, R. K., Brooks, J. A., and Grasman, B. T. 1995. The association of DNA damage to concentrations of mercury and radiocesium in largemouth bass. Environ. Toxicol. Chem. 14:661668.

Suzuki, K. T. 1992. Preparation of metallothioneins. In Metallothioneins, synthesis, structure and properties of metallothioneins, phytochelatins, and metal-thiolate complexes, eds. M. J. Stillman, C. F. Shaw II, and K. T. Suzuki, pp. 14-30. New York: VCH.

Urban, D. 1970. Raccoon populations, movement patterns and predation on a managed waterfowl marsh. J. Wildl. Manage. 34:372-382.

Wahba, Z. Z., Coogan, T. P., Rhodes, S. W., and Waalkes, M. P. 1993. Protective effects of selenium on cadmium toxicity in rats: Role of altered toxicokinetics and metallothionein. J. Toxicol. Environ. Health 38:171-182.

Whicker, F. W., Pinder, J. E., Bowling, J. W., Alberts, J. J., and Brisbin, I. L., Jr. 1990. Distribution of long-lived radionuclides in an abandoned reactor cooling reservoir. Ecol. Monogr. 60:471-496.

Workman, S. W., and McLeod, K. W. 1990. Vegetation of the Savannah River Site: Major Community Types. Publication SRO-NERP-19. Aiken, SC: Savannah River Ecology Laboratory.

Yurkow, E. J., and DeCoste, C. J. 1999. Effects of cadmium on metallothionein levels in human peripheral blood leukocytes: A comparison with zinc. J. Toxicol. Environ. Health 58:313-327.

Yurkow, E. J., and Makhijani, P. R. 1998. Flow cytometric determination of metallothionein levels in human peripheral blood lymphocytes: Utility in environmental exposure assessment. J. Toxicol. Environ. Health 54:445-457. 